\title{
PENGARUH EFEK EKSTRAK ETANOL DAUN SIRIH ( Piper Betle Linn.) SEBAGAI ANTIOKSIDAN TERHADAP LUKA BAKAR PADA KULIT PUNGGUNG KELINCI (Oryctolagus Cuniculus)
}

\author{
Muhammad Asri \\ Sekolah Tinggi Ilmu Kesehatan Mega Rezky Makassar \\ Email :muhammadasri324@gmail.com
}

\begin{abstract}
The burn are injuries to the skin where a response to the skin and subcutaneous tissue to the trauma experienced. The burn with partial thickness is a burn that does not damage the epithelial tissue of the skin and only damage some of the epithelial. This research aims to determine the effect of ethanol extract of betel leaf (Piper betle Linn.) As an antioxidant to burns on the skin back of the rabbit's (Oryctolagus Cuniculus). The experimental method was carried out experimentally, divided into 5 groups and treatment for 7 days, $P 1$ negatife control (made wound on the skin back of rabbit and smeared with vaseline flavum), P2 positif control (made wound on rabbit's skin back and smeared with bioplacenton ointment) P3 (made wound and ethanol extract of betel leaf with 5\% concentration), P4 (made wound and ethanol extract of betel leaves with 10\% concentration), P5 (made wound and ethanol extract of betel leaves with $15 \%$ concentration). The result of the research on the measurement of diameter of burn area on rabbit's skin back before and after treatment, group $I 2.5 \mathrm{~cm}$ and $2.4 \mathrm{~cm}$, group $I I 2.5 \mathrm{~cm}$ and $1.9 \mathrm{~cm}$, group III $2.2 \mathrm{~cm}$ and $1.9 \mathrm{~cm}$, group $I V 2.3 \mathrm{~cm}$ and $1.8 \mathrm{~cm}$, and group $V 2.3 \mathrm{~cm}$ and $1.6 \mathrm{~cm}$. The conclusion of ethanol extract of betel leaf (Piper betle Linn) at concentrations of $5 \%$, $10 \%$ and $15 \%$ as antioxidants can heal burns on the skin back of the rabbit's .
\end{abstract}

Key words: Ethanol extract of betel leaf, Burns, Antioxidants

\section{PENDAHULUAN}

Di Indonesia setiap tahunnya orang mengalami luka bakar dari kondisi ringan yang hanya merusak lapisan atas kulit sampai kondisi berat yang merusak jaringan otot. Berdasarkan catatan yang diperoleh, luka bakar menyebabkan 195.000 kematian/tahun di seluruh dunia terutama di negara miskin dan berkembang. Luka bakar yang tidak menyebabkan kematian pun ternyata menimbulkan kecacatan pada penderitanya .

Luka bakar merupakan kehilangan jaringan yang disebabkan kontak dengan sumber panas seperti air, api, bahan kimia, listrik, dan radiasi. Luka bakar akan mengakibatkan tidak hanya kerusakan 
Pengaruh efek ekstrak etanol daun sirih ( Piper Betle Linn.) sebagai antioksidan terhadap luka bakar pada kulit punggung kelinci (Oryctolagus Cuniculus)

kulit, tetapi juga amat memengaruhi seluruh sistem tubuh. ${ }^{1}$ Kulit dengan luka bakar akan mengalami kerusakan pada epidermis, dermis maupun jaringan subkutan tergantung faktor penyebab dan lamanya kulit kontak dengan sumber panas atau penyebabnya. Kedalaman luka bakar akan mempengaruhi kerusakan atau gangguan kematian sel-sel luka bakar akan mengakibatkan tidak hanya kerusakan kulit, tetapi juga amat mempengaruhi seluruh sistem tubuh pasien, semua luka bakar (kecuali luka bakar ringan atau luka bakar derajat I) dapat menimbulkan komplikasi berupa shock, dehidrasi dan ketidakseimbangan elektrolit, infeksi sekunder dan lain-lain. ${ }^{2}$

Salah satu alternatif mengobati luka bakar yaitu dengan memanfaatkan tanaman seperti daun sirih karena Daun sirih memiliki kandungan senyawa aktif berupa alkaloid, saponin, tanin, fenol dan flavonoid yang mempunyai kemampuan untuk membantu proses penyembuhan luka dan merangsang pertumbuhan sel - sel baru pada luka. ${ }^{3}$ Molekul bioaktif yang berperan sebagai antimikroba adalah minyak atsiri, sedangkan flavonoid dan fenol berperan sebagai antioksidan yan berfungsi untuk menunda atau menghambat reaksi oksidasi oleh radikal bebas. ${ }^{4}$

Sedangkan Antioksidan yang terdapat pada daun sirih seperti vitamin A dan vitamin C berperan menangkap radikal bebas yang dapat menyebabkan kerusakan membran sel. Cedera pada membran sel tersebut kemudian mengaktifkan histamin yang nantinya menjadi mediator sel radang. ${ }^{5}$

Berdasarkan uraian di atas, maka mendorong peneliti untuk mencari suatu pengobatan menggunakan ekstrak etanol daun sirih sebagai antioksidan terhadap penyembuhan luka bakar pada kulit punggung kelinci.

\section{METODE PENELITIAN}

\section{Jenis penelitian}

Penelitian ini merupakan eksperimen laboratorium yang bertujuan untuk mengetahui pengaruh efek ekstrak etanol daun sirih (Piper betle Linn) sebagai antioksidan terhadap luka bakar pada kulit punggung kelinci dengan melihat perubahan secara makroskopik.

\section{Alat dan bahan}

Alat - alat yang digunakan yaitu cawan porselin, gelas kimia (pyrex), gelas ukur (pyrex), tabung reaksi, timbangan analitik, batang pengaduk, aluminium foil, gunting bedah. Bahan- 
Pengaruh efek ekstrak etanol daun sirih ( Piper Betle Linn.) sebagai antioksidan terhadap luka bakar pada kulit punggung kelinci (Oryctolagus Cuniculus)

bahan yang digunakan yaitu ekstrak daun sirih, etanol, air suling, vaselin flavum, Bioplacenton.

\section{Prosedur penelitian}

\section{Perlakuan}

Pembuatan Luka Bakar menggunakan logam panas.Rambut pada daerah punggung kelinci dicukur, kemudian ditempeli logam panas ke punggung kelinci, sampai bagian dermis beserta jaringan yang terikat dibawahnya, sehingga terjadi pelepuhan pada kulit.

Perlakuan dibagi atas 5 kelompok sebagai berikut :

1. Kelompok1 : Kontrol Negatif, di buat luka pada kulit punggung kelinci dan diolesi vaselin flavum

2. kelompok 2 : Kontrol Positif, di buat luka pada kulit punggung kelinci dan
3. diolesi salep bioplacenton

4. Kelompok 3 : Dibuat luka dan pemberian ekstrak etanol daun sirih dengan konsentrasi $5 \%$

5. Kelompok 4 : Dibuat luka dan pemberian ekstrak etanol daun sirih dengan konsentrasi $10 \%$

6. Kelompok 5 : Dibuat luka dan pemberian ekstrak etanol daun sirih dengan konsentrasi $15 \%$

Perlakuan selama 7 hari, pengolesan perlakuan dilakukan secara merata 1 kali setiap hari, kemudian dilakukan pengamatan secara makroskopik perkembangan penyembuhan luka pada punggung kelinci dan Luka bakar dirawat hingga sembuh.

\section{HASIL PENELITIAN}

Tabel.1 Hasil pengukuran luka sebelum dan sesudah perlakuan.

\begin{tabular}{ccc}
\hline \multirow{2}{*}{ Perlakuan kelompok } & \multicolumn{2}{c}{ Hasil pengukuran diameter luka $(\mathbf{c m} / \mathbf{m m})$} \\
\cline { 2 - 3 } & Sebelum & Sesudah \\
\hline I & 2.5 & 2.5 \\
II & 2.5 & 1.9 \\
II & 2.2 & 1.9 \\
IV & 2.3 & 1.8 \\
V & 2.3 & 1.6 \\
\hline
\end{tabular}

Berdasakan tabel diatas dapat disimpulkan bahwa pemberian ekstrak etanol daun sirih (Piper betle Linn)pada konsentrasi 5\%, 10\% dan
$15 \%$ sebagai antioksidan dapat menyembuhkan luka bakar pada kulit punggung kelinci. 
Pengaruh efek ekstrak etanol daun sirih ( Piper Betle Linn.) sebagai antioksidan terhadap luka bakar pada kulit punggung kelinci (Oryctolagus Cuniculus)

\section{PEMBAHASAN}

Luka bakar disebabkan oleh perpindahan energi dari sumber panas ke kulit, dan Pengujian dilakukan secara bersamaan antara kelompok kontrol negatif, kelompok kontrol positif, dan kelompok ekstrak etanol daun sirih (Piper BetleLinn) dengan 3 konsentrasi berbeda, yang bertujuan untuk mengetahui konsentrasi maksimal dari ekstrak etanol daun sirih (Piper Betle Linn) dalam penyembuhan luka bakar pada kulit punggung kelinci. Konsentrasi ekstrak etanol daun sirih (Piper Betle Linn) terdiri dari konsentrasi 5\%, 10\%, dan $15 \%$. Sebelum melakukan pengujian hewan uji dikondisikan selama 1 minggu, mengontrol kesehatannya dan dapat menyesuaikan diri terhadap lingkungan baru.

Pada (P1) hewan uji terlebih dahulu dicukur menggunakan alat pencukur bulu dibagian punggung kelinci, hal ini bertujuan untuk memudahkan pembuatan luka bakar pada kulit punggung kelinci. (P2) pembuatan luka bakar dilakukan dengan cara menempelkan logam yang telah dipanaskan sebelumnya pada api, logam panas tersebut ditempelkan dipunggung kelinci yang sebelumnya telah dicukur bulunya selama 10 detik. (P3) yaitu pemberian kontrol Negatif (Vaselin flavum) mulai terlihat perubahan lukanya pada hari ke-5 dan penyembuhan yang tidak terlalu besar tetapi menunjukkan adanya proses penyembuhan. (P4) pemberian kontrol positif proses penyembuhanya lebih cepat karena bioplacenton yang digunakan sebagai kontrol positif merupakan salep yang digunakan sebagai salep luka bakar yang sudah terkenal dan telah mengalami beberapa proses pengujian baik uji praklinik maupun uji klinik dan pada salep bioplacenton yang digunakan memiliki zat aktif lebih dari satu sehingga proses penyembuhan luka bakar terjadi dengan cepat. (P3) pemberian ekstrak etanol daun sirih dengan konsentrasi $5 \%$ proses penyembuhan lukanya mulai terlihat pada hari ke-4 sedangkan pada gambar (P4) dan (P5) ekstrak etanol daun sirih dengan konsentrasi 10\% dan $15 \%$ proses penyembuhanya lebih cepat karena pada daun sirih mengandung molekul - molekul bioaktif seperti saponin, tannin, minyak atsiri, flavonoid, dan fenol yang mempunyai kemampuan untuk membantu proses penyembuhan luka serta nutrisi yang dibutuhkan untuk penyembuhan luka seperti vitamin $A$ dan vitamin C. Tannin membantu proses penyembuhan luka melalui 
Pengaruh efek ekstrak etanol daun sirih ( Piper Betle Linn.) sebagai antioksidan terhadap luka bakar pada kulit punggung kelinci (Oryctolagus Cuniculus)

peningkatan jumlah pembentukan pembuluh darah kapiler. Molekul bioaktif lain yang mempunyai peran sebagai antimikroba adalah minyak atsiri. Flavonoid dan fenol berperan sebagai antioksidan yang berfungsi untuk menunda atau menghambat reaksi oksidasi oleh radikal bebas.

Antioksidan diperlukan untuk mencegah stres oksidatif.Stres oksidatif adalah kondisi ketidakseimbangan antara jumlah radikal bebas yang ada dengan jumlah antioksidan di dalam tubuh. Radikal bebas merupakan senyawa yang mengandung satu atau lebih elektron tidak berpasangan dalam orbitalnya, sehingga bersifat sangat reaktif dan mampu mengoksidasi molekul di sekitarnya (lipid, protein, DNA, dan karbohidrat). Antioksidan bersifat sangat mudah dioksidasi, sehingga radikal bebas akan mengoksidasi antioksidan dan melindungi molekul lain dalam sel dari kerusakan akibat oksidasi oleh radikal bebas atau oksigen reaktif .

Antioksidan pada luka bakar secara signifikan dapat mengurangi jumlah kerusakan pada jaringan kulit yang disebabkan oleh peroksidasi lipid dan dapat mengganggu reaksi kimia pada kulit yang terbakar, dan mengalami perlambatan penyebaran, sehingga cukup ampuh dalam mengobati luka bakar pada kulit. Antioksidan atau Vitamin C penting untuk penyembuhan luka, hal ini meningkatkan kekuatan luka seperti menyembuhkan, dan membantu dengan penciptaan kolagen di kulit, antioksidan juga penting dalam penciptaan pembuluh darah baru, dan membantu penyerapan zat besi .

\section{KESIMPULAN}

Berdasarkan penelitian yang dilakukan dapat ditarik kesimpulan bahwa ekstrak etanol daun sirih (Piper Betle Linn) pada konsentrasi 5\%,10\% dan $15 \%$ dapat menyembuhkan luka bakar pada kulit punggung kelinci (Oryctolagus cuniculus)

\section{DAFTAR PUSTAKA}

1. Balqis U. Healing Process Of Burns Using Ambarella Leaf (Spondias dulcis F.) and Vaselin in Rats (Rattus norvegicus). 2014.

2. Lusy PW. Efek penyembuhan luka bakar gel ekstrak etanol daun sirih ( piper betle) pada kulit punggung tikus wistar (Skripsi). Surakarta; 2009.

3. Moeljanto RD. Khasiat \& Manfaat Daun Sirih: Obat Mujarab dari Masa ke Masa. Jakarta : Agromedia Pustaka; 2003.

4. Jin L, et al. Phenolic compound and antioxidant activity of buld wxtrac of six lilium species native to China. 2012. 
Pengaruh efek ekstrak etanol daun sirih ( Piper Betle Linn.) sebagai antioksidan terhadap luka bakar pada kulit punggung kelinci (Oryctolagus Cuniculus)

5. Mawarsari T. Uji aktivitas tikus putih jantan galur Sprague penyembuhan luka bakar ekstrak dawley (Skripsi). Jakarta; 2015. etanol umbi talas Jepang pada 